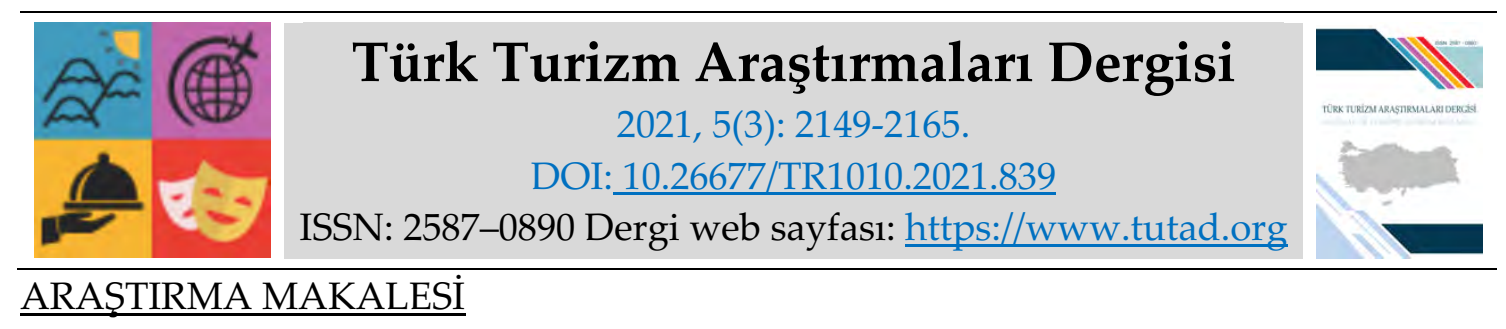

\title{
Doğu Karadeniz'deki 5 Yıldızlı Konaklama İşletmelerine Yönelik Çevrimiçi Müşteri Şikâyetlerinin İncelenmesi
}

Dr. Öğr. Üyesi Ömür UÇAR, Giresun Üniversitesi, Turizm Fakültesi, Giresun, e-posta: omur.ucar@giresun.edu.tr ORCID: https://orcid.org/0000-0002-3570-7247

Mustafa KIRHASANOĞLU, Yüksek Lisans Öğrencisi, Giresun Üniversitesi, Sosyal Bilimler Enstitüsü, Giresun, e-posta: kirhasanoglu@gmail.com

ORCID: https://orcid.org/0000-0001-7389-2378

Öz

İnternet ve sosyal medyanın iletişim ve bilgi edinme amaçlı yoğun kullanılmaya başlanmasıyla birlikte tüketiciler işletme, ürün ya da hizmet ile ilgili yapılan yorumları inceleyebilmekte ve deneyimleriyle ilgili yorumlar yapabilmektedirler. Buna ek olarak çevrimiçi ortamlarda yapılan olumlu ve olumsuz yorumlar tüketicilerin kararlarını etkileyebilmektedir. Bu bağlamda bu araştırmada Doğu Karadeniz'de yer alan beş yıldızlı otellere yönelik müşteri şikâyetlerinin kategorize edilerek ortaya koyulması amaçlanmaktadır. Bu kapsamda tripadvisor.com ve sikayetvar.com web sayfalarında yer alan 520 adet şikâyet içeren yorum nitel araştırma yöntemi kullanılarak içerik analizi tekniğiyle incelenmiş ve 1312 şikâyet kategorize edilmiştir. Yapılan içerik analizi sonucunda müşteri şikâyetleri 5 ana ve 28 alt kategoriye ayrılmıştır. Çalışma sonucunda en yüksek şikâyet alan konuların oda ekipman ve malzemeleri, yiyecek-içecek çeşitliliği, fiyatlandırma, yabancı müşteriler lehine ayrımcılık yapılması, personel tutum ve davranışı ve havuz, SPA, hamam olduğu tespit edilmiştir. Araştırmanın sadece "tripadvisor.com" ve "şikayetvar.com" web sayfalarında ki şikâyetleri içermesi bu araştırmanın kısıtı olarak görülmektedir.

Anahtar Kelimeler: Çevrimiçi Şikâyet, Müşteri Şikâyeti, Şikâyet Siteleri, Konaklama İşletmeleri, Doğu Karadeniz.

Makale Gönderme Tarihi: 13.06 .2021

Makale Kabul Tarihi: 05.09.2021

Önerilen Atıf:

Uçar, Ö. ve Kırhasanoğlu, M. (2021). Doğu Karadeniz'deki 5 Yıldızlı Konaklama İşletmelerine Yönelik Çevrimiçi Müşteri Şikâyetlerinin İncelenmesi, Türk Turizm Araştırmaları Dergisi, 5(3): 2149-2165.

(c) 2021 Türk Turizm Araştırmaları Dergisi. 


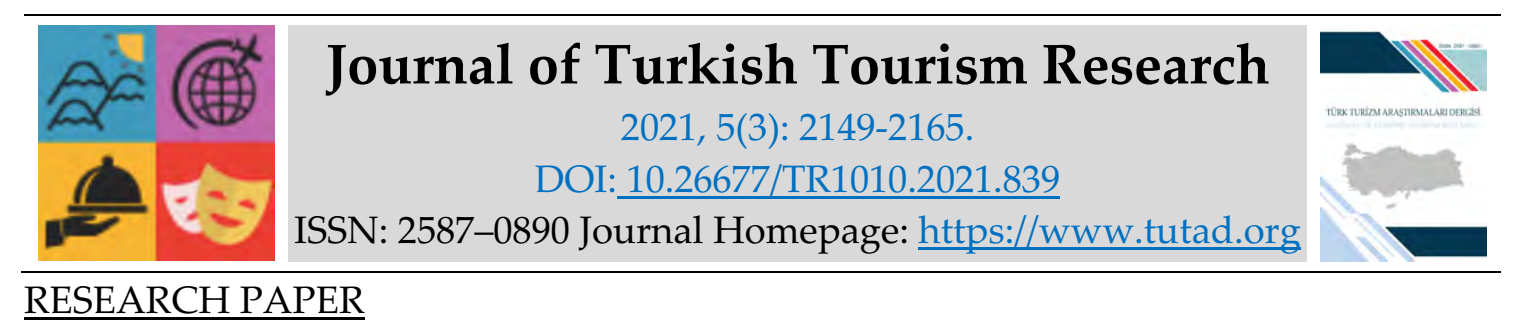

\title{
Investigation of Online Customer Complaints Against 5-Star Accommodation Businesses in the Eastern Black Sea Region
}

Assistant Prof. Dr. Ömür UÇAR, Giresun University, Faculty of Tourism, Giresun, e-mail: omur.ucar@giresun.edu.tr ORCID: https://orcid.org/0000-0002-3570-7247

Mustafa KIRHASANOĞLU, MSc. Student, Giresun University, Social Sciences Institute, Giresun, e-mail: kirhasanoglu@gmail.com

ORCID: https://orcid.org/0000-0001-7389-2378

\begin{abstract}
With the intensive use of the internet and social media for communication and information purposes, consumers can examine the comments made about the business, product or service and make comments about their experiences. In addition, positive and negative comments made online can affect consumers' decisions. In this context, in this research, it is aimed to categorize and reveal customer complaints about five-star hotels in the Eastern Black Sea Region. In this context, 520 comments containing complaints on the websites of tripadvisor.com and sikayetvar.com were analyzed using the qualitative research method, using the content analysis technique, and 1312 complaints were categorized. As a result of the content analysis, customer complaints were grouped into 5 main and 28 sub-categories. As a result of the study, it was determined that the subjects that received the highest complaints were room equipment and materials, food and beverage variety, pricing, discrimination in favor of foreign customers, staff attitudes and behavior, and pool, SPA, Turkish bath. The limitation of this research is that the research only includes the complaints on the "tripadvisor.com" and "sikayetvar.com" web pages.
\end{abstract}

Keywords: Online Complaints, Customer Complaints, Complaint Sites, Accommodation Businesses, Eastern Black Sea.

Received: 13.06 .2021

Accepted: 05.09.2021

Suggested Citation:

Uçar, Ö. and Kırhasanoğlu, M. (2021). Investigation of Online Customer Complaints Against 5Star Accommodation Businesses in the Eastern Black Sea Region, Journal of Turkish Tourism Research, 5(3): 2149-2165.

(C) 2021 Türk Turizm Araştırmaları Dergisi. 


\section{Gíriş}

Bilgi iletişim teknolojilerinde yaşanan gelişmeler ile birlikte insanların hayatına dâhil olan internetin; dünya çapında yayın kabiliyetine, etkin bir bilgi aktarma mekanizmasına ve konum fark etmeksizin insanlar arasında bir etkileşim ortamına sahip olduğu kabul edilmektedir (Au vd., 2009: 75). İnternetin hayatı kolaylaştıran özellikleri sayesinde artık tüketiciler market alışverişinden kitaplara, eğlenceden bilgi edinmeye ve diğer birçok hizmeti çevrimiçi ortamlarda bulmayı beklemektedirler. İnternetin sağladığı iletişim kolaylığı ve erişilebilirliği ile birlikte sosyal ağlar popüler olmaya ve küresel çapta birçok insan tarafından kullanılmaya başlanmıştır (Kavoura, 2014: 493). Günümüzde aktif sosyal medya kullanıcılarının sayısı 3,80 milyar ile dünya nüfusunun \%49'una denk gelmektedir ve bir kişi günde ortalama 2 saat 24 dakikasını sosyal medyada geçirmektedirler (Kemp, 2020). Medya işletmelerinden spor kulüplerine, ünlülerden bireysel kullanıcılara kadar dünya nüfusunun önemli bir bölümü özellikle de genç nüfus bir nedenle sosyal medyayı kullanmaktadır (Ly, 2020: 2). İnternet tabanlı sosyal medyanın ortaya çıkışı, bir kişinin ürünler ve bunları sağlayan şirketler hakkında yüzlerce hatta binlerce başka insanla iletişim kurmasını mümkün kılmıştır. Her alanda etkisi hissedilen internetin turizm sektörü üzerinde de önemli etkileri olmuştur. Bu etkileșim ile internet ve sosyal medya, turizm ürünleri hakkında geleneksel kaynaklar yerine sosyal ağ siteleri aracılığıyla bilgi toplamayı tercih eden turistler için ana güvenilir bilgi kaynaklarından biri haline gelmiştir (Lu ve Stepchenkova, 2015: 123).

Sosyal medya kullanımının gittikçe artmasıyla bu platformlarda yer alan yorum ve şikâyetler işletmeler için önemli birer geri dönüt durumuna gelmiştir. Sosyal medya kullanıcıları işletme, ürün ve hizmetlerle ilgili kendi deneyimlerini sosyal medya platformlarında paylaşırken, diğer kullanıcıların yorum ve fikirlerine de kolayca ulaşarak fikir edinebilmektedirler (Hsu ve Lin, 2008: 67). Gerçek deneyimlerin kullanıcılar tarafından sosyal medya platformlarında paylaşılması ve paylaşımların kısa sürede birçok kullanıcıya ulaşması sosyal medyada yapılan yorumların tüketicilerin karar verme süreçlerinde geleneksel yöntemlere göre daha etkili bir araç durumuna gelmesine sebep olmuştur (Garay, 2019: 3). Turizm ürünlerinin kullanıcı deneyimlerine bağlılığı turizm sektörünün bu oluşan durumdan en fazla etkilenen sektörlerden biri olmasına yol açmıştır (Zheng vd., 2009: 725). Çünkü günümüzde tüketiciler bir turizm ürünü satın almadan önce sosyal medyada araştırma yapmakta, insanların deneyimlerini okumakta ve satın alacağı ürün ile ilgili yorumları incelemektedir. Dolayısıyla sosyal medyada yer alan ürün ve marka şikâyetleri turizm tüketicilerinin karar verme süreçlerini önemli ölçüde etkilemektedir (Erol vd., 2019: 3291). Bu bağlamda sosyal medya platformlarında yer alan şikâyetler, tüketiciler açısından karar verme sürecinde, işletmeler açısından ise eksikliklerini görme ve önlem alma aşamasında önem arz etmektedir. Literatürde yer alan çalışmalar incelendiğinde çevrim içi şikâyetleri inceleyen çalışmaların genellikle Ege, Akdeniz ve Marmara bölgesinde yer alan konaklama işletmelerini ele aldığı görülmektedir. Bu araştırmanın, Doğu Karadeniz'de yer alan konaklama işletmelerine yönelik şikâyetlerin incelendiği ilk araştırmalardan biri olması sebebiyle literatüre yapılacak katkının önemli olduğu düşünülmektedir.

\section{Şikâyet Kavramı}

Günümüzde şikâyet, hayatın içerisine yerleşmiş, gündelik yaşamın bir parçası haline gelmiştir. İnsanlar farkında olarak ya da olmayarak her gün trafikten, işlerinden, işverenlerinden ve daha birçok benzeri durumdan şikâyet edebilmektedirler. Heyecanla satın alınan bir ürün veya bir hizmetten beklentinin karşılanamaması durumunda insanlar yakınabilir, sinirlenebilir ya da şikâyet etme gibi tepkiler gösterebilirler. Literatür incelendiğinde şikâyet kavramı ile ilgili birçok farklı tanıma rastlamak mümkündür. Genel bir bakış açısıyla değerlendirildiğinde şikâyet 
kavramı, bir olaydan veya durumdan hoşnut olmama durumunu ifade etmektedir (Aymankuy, 2011: 2020). Bir başka tanımda Burucuoğlu (2011: 43) ise şikâyet kavramını kişilerin beklentilerinin karşılanmaması durumunun söz ile ifade edilmesi şeklinde daha yalın bir halde tanımlamıştır. Kowalski (1996: 183) ise bir kişinin duygularını yansıtmak veya kişisel hedeflerine ulaşmak amacıyla memnun kalmadığı bir durumu ifade etmesini şikâyet olarak tanımlamıştır. Literatürde yer alan tanımlara baktığımızda şikâyetin ortaya çıkması için memnun olunmayan bir durum veya olayın olması ve oluşan bu durumun ifade edilmesi gerekmektedir.

Her alanda olduğu gibi ticaret hayatında da insanlar memnun olmadıkları ürün, hizmet veya durumlarla karşılaşabilmektedirler. Tüketiciler bir ürün, olay, durum ya da hizmet ile alakalı memnuniyetsizliklerini belirtmek amacıyla duygularını ifade edebilmektedirler. Tüketicilerin memnun kalmadıkları mal ve hizmet tecrübesinin ardından duygularını ifade etmek ve memnuniyetsizliklerini gidermek adına ortaya koydukları davranışlar müşteri şikâyeti olarak tanımlanmaktadır (Çakıcı ve Güler, 2015: 220). Bell vd., (2004: 116) müşteri şikâyetinin kısaca olumsuz müşteri geri dönütü olduğunu belirtmişlerdir. Şikâyet eden müşteriler hizmet veya ürün aldıkları işletmelere dönüş yaparak memnuniyet düzeylerini de belirtmiş oldukları için müşteri şikâyetleri, müşteri memnuniyetsizliğinin ölçülmesinde önemli bir göstergedir (Lertputtarak ve Samokhin, 2017: 218). Müşterilerin fikirlerini öğrenmeyi sağlayan müşteri şikâyetleri, işletmelerin kendilerini geliştirmeleri açısından önemli bir yer tutmaktadır (Riesenberger ve Sousa, 2010). Benzer şekilde Namkung vd., (2011: 498) tüketici şikâyetlerinin, işletmelere sundukları ürün ve(ya) hizmetlerle ilgili olumsuzluklar hakkında bilgi vererek işletmelerin üretim ve/ya yönetim süreçlerinde iyileştirme yapmalarına imkân verdiğini belirtmektedirler. Tüketicilerin şikâyetlerini olabildiğince erken ele almamak, tüketicilerin olumsuz ağızdan ağıza iletişim yapmalarına veya çıkış niyetlerine yol açabilmekte ve bu durum işletmenin faaliyetlerini olumsuz etkileyebilmektedir (Yüksel vd., 2006). Dolayısıyla tüketicilerin şikâyet davranışları işletmeler için faydalı geri bildirimler olabilmekte ve bu şikâyetleri erkenden ele almak önem arz etmektedir.

Tüketici şikâyet davranışı Rogers vd., (1992: 83) tarafından memnun olmayan müşterilerden kaynaklanan bir eylem veya eylemler olarak tanımlanmıştır. Yine bir başka tanımda Landon (1980) tüketici şikâyet davranışını tüketicilerin işletmenin dağıtım kanalına ya da idaresinde yer alan diğer uygulamalara yönelik memnun olmama durumunu ifade etmesi olarak belirtmektedir. Tüketici şikâyet davranışı ile ilgili literatürde tüketicilerin şikâyet davranışlarının nedenlerini bütünsel bir şekilde değerlendiren modeller yer almaktadır. Tüketici şikâyet davranışın 1970 yılında ilk olarak kavramlaştıran Hirschman siyasi partilere odaklanırken üyelerin siyasi strateji ve hedefleri değiştirebilme olasılığı üzerinde durmuştur (Tronvoll, 2007: 286). Hirschman'a (1970) göre tüketici davranışının "Çıkış" (müşterinin işletmeyle bağlantısını kesmesi), "Ses" (müşterinin işletmeye veya üçüncü bir tarafa memnuniyetsizliğini ifade etmesi) ve "Sadakat" (müşteri herhangi bir eylemde bulunmaması) olmak üzere üç boyutu yer almaktadır. Day ve Landon (1977) tarafından ortaya koyulan tüketici şikâyet modelinde ise memnun olmayan tüketicilerin üç farklı şekilde eyleme geçtikleri belirtilmektedir. Tüketicilerin eyleme geçme yöntemlerinden birincisinde tüketicilerin sorunlardan kaçınarak herhangi bir eylemde bulunmadıkları ve pasif kaldıkları ifade edilirken ikinci yöntemde tüketiciler arkadaşlarını ve yakınlarını konuyla ilgili bilgilendirerek bireysel olarak eyleme geçmektedirler. Üçüncü yöntemde ise memnun olmayan tüketiciler işi biraz daha ileri boyuta taşıyarak memnuniyetsizliklerini tüketici derneklerini ve yasal yolları devreye sokarak belirtmektedirler (Day ve Landon, 1977: 233). Singh (1990: 58) ise ortaya koyduğu modelinde tüketici şikâyeti davranışını üç boyutta ele almıştır. Bu boyutlar; Satıcıya yönelik eylemleri içeren "Sesli Tepkiler", arkadaşlara ve akrabalara ağızdan ağıza iletişim ve marka ya da satıcı değiştirme eylemlerini 
içeren "Özel Tepkiler" ve harici kurumlara veya yasal yollara başvurma eylemlerini içeren "Üçüncü Taraf Tepkiler" şeklinde ifade edilmiştir.

Tüketiciler şikâyet davranışlarını belirtmek için farklı kanallar seçmektedirler. Susskind (2005: 154) şikâyet kanallarını yönetici ile yüz yüze görüşme, çalışanla yüz yüze görüşme, yazılı (mektup, e-posta, internet) şikâyette bulunma ve yorum kartıyla şikâyet bildirme şeklinde kategorize etmiştir. Geçmişte insanlar çiftler halinde veya küçük gruplar halinde iletişimde bulunurken, günümüzde internet insanların büyük gruplar halinde iletişim kurmasına imkân sağlayan geniş bir kitle iletişim aracına dönüşmüştür. Bilgi iletişim teknolojilerinde yaşanan bu gelişim ile birlikte tüketiciler interneti olumlu ve olumsuz deneyimlerini bildirmek amaciyla bir kanal olarak kullanmaya başlamışlardır (Berry vd., 2018: 76). Ortaya çıkan bu yeni kanal yoluyla tüketiciler memnun olmadıkları durumları rahat bir şekilde ilgili yerlere ulaştırabilmekte ve taleplerine cevap alabilmektedirler. Dolayısıyla deneyimlenmiş ürün veya hizmetlerle ilgili ağızdan ağıza iletişimlerin bir sonucu olarak birçok çevrimiçi geri bildirim / inceleme forumu ortaya çıkmıştır (Au vd., 2009: 75).

Turizm sektörü, çevrimiçi rezervasyonlardaki artış ve karar verme sürecinin misafirlerin deneyimleriyle ilgili yorumlardan giderek daha fazla etkilenmesi nedeniyle bu yeni iletişim kanalından en fazla etkilenen sektörlerden bir tanesi olmuştur (Zheng vd., 2009: 719). İnsanlar seyahate ya da tatile çıkmadan önce gidecekleri destinasyonlar ve o bölgede yer alan işletmeler hakkında internette araştırma yapmakta ve bilgi toplamaktadır. Ayrıca günümüzde pek çok turist, seyahatlerinde internet kullanıcılarının önerdiği otelleri sıklıkla kullanmaktadır (Sigala vd., 2012: 145). Dolayısıyla daha önce bu destinasyon ve işletmeleri deneyimleyen tüketicilerin yorumlarının potansiyel tüketicilerin karar verme süreçlerini de etkileyebildiği söylenebilir. Ayrıca bir işletme, turistik ürün veya bölge hakkında yapılan olumlu yorumlar turist tercihlerini olumlu anlamda etkilemektedir (İnanır ve Ongun, 2019). İnternette yer alan çevrimiçi platformlar, seyahat edenlere karar verme süreçlerinin her aşamasında yardımcı olabilecek bir araç olarak kabul edilmektedir (Aktan ve Koçyiğit, 2016: 68). Bu durum konaklama işletmeleri ile ilgili online platformlarda yer alan yorumların önemini ortaya koymaktadır. Turizm sektöründe hizmet alan tüketiciler konakladıkları turizm işletmesiyle veya deneyimledikleri turizm ürünüyle ilgili görüşlerini "tripadvisor.com" ya da "sikayetvar.com" gibi platformlarda paylaşmaktadırlar. "tripadvisor.com", Similarweb sıralamasına göre dünyanın en popüler online seyahat platformudur (www.similarweb.com). 49 ülke ve 28 dilde hizmet veren "tripadvisor.com" web sitesinde 900 milyon civarında yorum bulunmaktadır (www.tripadvisor.mediaroom.com). "tripadvisor.com" web sitesinde kullanicılar turizm ve seyahat ile ilgili olumlu ve olumsuz yorumlar yapabilmektedirler. "sikayetvar.com" web sitesi ise marka ve ürünlerle ilgili sorunları şikâyet etmek ve bu sorunlara çözüm bulmak amacıyla hizmet veren bir platformdur. 7 milyona yakın üyesi olan ve 130 binin üzerinde markanın kayıtlı olduğu web sayfasını ayda 15-20 milyon internet kullanıcısı ziyaret etmektedir (www.sikayetvar.com).

Literatürde online müşteri şikâyetlerini inceleyen farklı çalışmalar mevcut olup bu çalışmalardan bazıları kronolojik olarak şu şekilde sıralanabilir:

Au vd., (2009) çalışmalarında Hong Kong'ta yer alan konaklama işletmeleri hakkında Tripadvisor web sitesinde yer alan 453 şikâyet içerikli yorumu incelemişlerdir. Araştırmacılar elde ettikleri verilere göre şikâyetleri dokuz kategoriye ayırmışlardır. Yapılan çalışmada, hizmet kalitesi ile alakalı şikâyetlerin yüksek olması nedeniyle müşterilerin sunum ve uygunsuz personel davranışı gibi bazı durumlardan memnun olmadıkları ifade edilmiştir. Araştırmacılar donanım olarak kabul edilen alan, tasarım vb. ve yazılım olarak kabul edilen hizmet, temizlik vb.'nin müşteri memnuniyeti sağlanmasında eşit öneme sahip olduğunu ortaya koymuşlardır. 
Vásquez (2010) çalışmasında müşteri şikâyetlerinin, literatürde yer alan önceki araştırmalarda tanımlanan şikâyetlerin bazı tanımlayıcı özelliklerini ne ölçüde sergilediğini belirlemek için Tripadvisor web sitesinde yer alan en kötü 100 şikâyeti incelemiştir. Çalışmada, tüketicilerin şikâyetlerini genelde olumlu bir değerlendirmeyle birlikte ifade etme eğiliminde oldukları belirtilirken şikâyetlerin büyük kısmının, şikâyetçinin beklentisinin karşılanmaması ile ilgili olduğu ortaya koyulmuştur. Araştırmacı tripadvisor.com'daki şikâyetlerin genel olarak uyarı veya tehdit şeklinde değil öneri ya da tavsiye tarzında olduğu ve çoğunun dolaylı (üçüncü taraf) şikâyetler olarak kabul edilebileceğini ifade etmektedir.

Alrawadieh ve Demirkol (2015) İstanbul'da yer alan 5 yıldızlı konaklama tesisleri hakkında çevrimiçi ortamda yapılan şikâyetleri belirlemek üzere Tripadvisor web sayfasında yapılan 219 şikâyeti incelemiştir. Çalışma sonunda şikâyet oranının en yüksek olduğu konular fiyat politikası, personel davranışları, tesislerin durumu ve verilen hizmetin kalitesi olarak belirtilmiştir. Ayrıca çalışma kapsamında incelenen 219 şikâyetin yarısından azına dönüş yapılarak cevap verildiği ifade edilmiştir.

Lertputtarak ve Samokhin'in (2017) Pattaya'daki dört yıldızlı oteller hakkında "booking.com" da yar alan olumsuz çevrimiçi müşteri yorumlarının içeriğini analiz ederek 1350 olumsuz yorumu incelemişlerdir. Çalışmada müşteri şikâyetlerinin personel, oda, banyo, restoran/kahvaltı, otopark, lokasyon ve otel tesisleri olmak üzere yedi kategoriden oluştuğu ortaya koyulmuştur. Araştırmacılar elde ettikleri bulgulara göre otel yöneticilerinin personel eğitimine odaklanması gerektiği, otellerde oda ve banyoların iyi temizlenmesi ve yenilenmesinin önemli olduğunu belirtmişlerdir. Ayrıca otellerde kullanılan yiyeceklerin temiz ve taze olması, otel otopark ve tesislerinin bakımlarının yapılması ve güvenlik sistemlerinin iyileştirilmesi gerektiğini ifade etmişlerdir.

Zengin ve Haliloğlu (2020) şikâyetleri kategorilere ayırmak, en yüksek şikâyet alan konuları ve şikâyetlere yapılan dönüş oranlarını belirlemek amacıyla Sakarya'da yer alan oteller hakkında Şikayetvar.com ve Tripadvisor.com web sitelerinde yer alan 305 şikâyeti incelemişlerdir. Şikâyetlerin 8 ana tema ve 48 alt temada kategorize edildiği çalışmada en yüksek şikâyet oranının beş yıldızlı otellerde olduğu ve en fazla şikâyet alan konuların sırasıyla otelin özellikleri/imkânları, yönetim politikası, personel ve oda olduğu ifade edilmiştir. Ayrıca işletmeler tarafından şikâyetlerin üçte ikisine dönüş yapılmasına rağmen bu oranın müşterilerin memnuniyet düzeyine etkisinin düşük düzeyde kaldığı ortaya koyulmuştur.

Literatürde konaklama işletmeleri ile ilgili çevrimiçi şikâyetleri inceleyen birçok çalışma yer almasına rağmen Doğu Karadeniz'de bu alanda yapılmış bir çalışmaya rast gelinmemiştir. Bu bilgiler ışığında bu çalışmanın temel amacı belirli internet geri bildirim platformlarında yer alan, Doğu Karadeniz'de faaliyet gösteren beş yıldızlı otellere yönelik müşteri şikâyet ve olumsuz yorumlarının hangi kategorilerde toplandığının ortaya koyulmasıdır. Literatürde Doğu Karadeniz bölgesinde otellere yönelik müşteri şikâyetlerini inceleyen bir araştırma olmaması dikkate alınarak çalışma için aşağıda ki araştırma soruları geliştirilmiştir.

1- Doğu Karadeniz'de yer alan otel işletmelerinde çevrimiçi olumsuz yorum/şikâyetler hangi kategorilerde toplanmaktadır?

2- Doğu Karadeniz'de yer alan otel işletmelerinde olumsuz yorum/şikâyette bulunanların demografik özellikleri nelerdir?

3- Doğu Karadeniz'de yer alan otel işletmelerinde en yüksek olumsuz yorum/ şikâyet alan konular hangileridir?

4- $\quad$ Doğu Karadeniz'de yer alan otel işletmelerine yönelik yapılan çevrimiçi olumsuz yorum/şikâyetlere dönüş oranı kaçtır? 


\section{YÖNTEM}

Çalışmada nitel araştırma yöntemi kullanılmıştır. Çevrimiçi platformlarda Doğu Karadeniz'de yer alan 5 yıldızlı otellerle ilgili yapılan şikâyetler nitel araştırma yöntemlerinde kullanılan bir veri analiz tekniği olan içerik analizi yöntemiyle analiz edilmiştir. İçerik analizi yöntemi kullanım alanlarına göre her türlü görsel, sözel, yazılı, sembolik ve iletişimsel veriden tekrarlanabilir ve geçerli çıkarımlar yapmak için kullanılan bir veri analiz yönetimidir (Krippendorff, 2004: 21). İçerik analizi yöntemi son yıllarda turizm çalışmalarında sıklıkla başvurulan önemli bir yöntem haline gelmiştir (Camprubí ve Coromina, 2016: 134). Bu doğrultuda içerik analizi yöntemini kullanarak birçok araştırmacı (Çakar vd., 2018; İnanır, 2019; Ongun vd., 2019; İnanır vd., 2019; Çakar ve Aykol, 2019; Çakar ve Uzut, 2020) turizmin farklı konularında araştırmalar gerçekleştirmiştir.

Veriler "tripadvisor.com" ve "şikayetvar.com" web sayfalarında Doğu Karadeniz'de yer alan otel işletmelerine yönelik 2021 yılı Temmuz ayına dek yapılan yorumlardan derlenmiştir. Doğu Karadeniz Bölgesi'nde yer alan Rize, Artvin, Trabzon, Ordu, Giresun, Gümüşhane ve Bayburt İl Kültür ve Turizm Müdürlükleri web sayfalarında yer alan turizm belgeli işletme listeleri incelenerek bu illerde yer alan beş yıldızlı konaklama işletmeleri belirlenmiştir. Bu verilere göre Trabzon'da beş, Rize'de dört ve Ordu'da üç olmak üzere Doğu Karadeniz'de toplam 12 adet beş yıldızlı otel yer almaktadır. Rize' de yer alan beş yıldızlı otellerden bir tanesi ile ilgili herhangi bir yorum bulunmaması sebebiyle bu işletme araştırma kapsamı dışında bırakılmıştır. Tripadvisor.com web sayfasında bu otellerle ilgili toplam 2055 yorum yer alırken bunlardan $485^{\prime} \mathrm{i}$ orta, berbat ve kötü kategorisinde yer almaktadır. Bu çalışma kapsamında diğer ele alınan sikayetvar.com web sayfasında ise bu otellerle ilgili 35 şikâyette bulunulmuştur. Toplamda 520 müşteri şikâyeti incelenen bu araştırmada içerik analizi yöntemiyle şikâyetlerin sayısı her otel için tek tek, şikâyetle ilgili ek bilgilerinde yer aldığı, bir veri toplama klasörüne kaydedilmiş ve ardından araştırmacılar tarafından kodlanarak kategorilere ayrılmıştır.

\section{BULGULAR}

Araştırma kapsamında tripadvisor.com ve sikayetvar.com web sayfalarında, Doğu Karadeniz'de yer alan 5 yıldızlı konaklama işletmelerine yönelik 2090 yorum yapıldığı tespit edilmiştir. Bu yorumlar içerisinde $485^{\prime} \mathrm{i}$ tripadvisor.com web sayfasından, 35'i de sikayetvar.com web sayfasından olmak üzere toplamda 520 adet şikâyet içeren yorum analize tabi tutulmuştur. Bu şikâyetler 5 ana kategori ve 28 alt kategoride gruplandırılmış, toplamda 1312 şikâyet kategorize edilmiştir. Şikâyette bulunan müşterilerin, bir yorumun içinde birden fazla şikâyette bulundukları, bazı durumlarda da olumlu yorumlarla birlikte şikâyette bulundukları tespit edilmiştir.

Tablo 1. İllere Göre Otel Sayıları, Yapılan Toplam Yorum, Şikâyet, Yanıtlanan Şikâyet Sayıları ve Şikâyetlere Yanıt Verilme Oranları

\begin{tabular}{|c|c|c|c|c|c|}
\hline & $\begin{array}{c}\text { Yorum } \\
\text { Sayısı }\end{array}$ & $\begin{array}{c}\text { Şikâyet } \\
\text { Sayısı }\end{array}$ & $\begin{array}{c}\text { Şikâyet/ } \\
\text { Yorum Oranı }\end{array}$ & $\begin{array}{c}\text { Yanitlanan } \\
\text { Şikâyet Sayısı }\end{array}$ & $\begin{array}{c}\text { Şikâyetlere Yanıt } \\
\text { Verilme Oranı }\end{array}$ \\
\hline Trabzon & 1493 & 302 & $\% 20,23$ & 232 & $\% 76,82$ \\
\hline Rize & 313 & 110 & $\% 35,14$ & 37 & $\% 33,64$ \\
\hline Ordu & 284 & 108 & $\% 38,03$ & 29 & $\% 26,85$ \\
\hline Toplam & 2090 & 520 & $\% 24,88$ & 298 & $\% 57,31$ \\
\hline
\end{tabular}


Tablo 1'de yer alan yorum sayıları incelendiğinde en fazla yorum sayısının olduğu il Trabzon iken bu ili Rize ve Ordu illeri takip etmektedir. Toplam yorum sayısının yaklaşık dörtte birinin şikâyet içerikli olduğu, Rize ve Ordu illerinde yapılan yorumların daha fazla şikâyet içerdiği görülmektedir. Araştırma kapsamında incelenen web sayfalarında yer alan şikâyetlerin \%57,31'inin yanıtlandığı, Rize ve Ordu illerine göre Trabzon ilinde şikâyetlerin yanıtlanma oranının daha yüksek olduğu tespit edilmiştir. Ordu ilinde şikâyetlere yanıt oranının \%26,85 ile diğer illere göre en düşük oranda olduğu görülmüştür.

Tablo 2. Şikâyet Bildiren Kişilerin Cinsiyetleri

\begin{tabular}{|l|cc|c|c|c|c|}
\hline \multirow{2}{*}{} & \multicolumn{2}{|c|}{ Kadın } & \multicolumn{2}{c|}{ Erkek } & \multicolumn{2}{c|}{ Belirtilmemiş } \\
\cline { 2 - 7 } & Sayı & Oran $\%$ & Sayı & Oran \% & Sayı & $\%$ \\
\hline Trabzon & 88 & 28,39 & 167 & 53,87 & 55 & 17,74 \\
\hline Rize & 42 & 38,53 & 56 & 51,38 & 11 & 10,09 \\
\hline Ordu & 33 & 32,67 & 57 & 56,44 & 11 & 10,89 \\
\hline Toplam & 163 & 31,35 & 280 & 53,85 & 77 & 14,80 \\
\hline
\end{tabular}

Tablo 2' de şikâyet bildiren kişilerin \%53,85'inin erkek olduğu görülmektedir. Şikâyet bildirenler arasında kadınların oranının tüm illerde erkek oranından daha düşük olduğu $(\% 31,35)$ tespit edilmiştir. Trabzon ilinde şikâyet bildiren kadınların oranının diğer illere göre en düşük (\%28,39) olduğu görülmektedir. Ayrıca şikâyet bildiren kişilerin \%14,8'inin de cinsiyetlerini belirtmediği görülmektedir.

Tablo 3. Seyahat Türüne Göre Şikâyette Bulunanların Sayısı ve Oranı

\begin{tabular}{|l|c|c|}
\hline \multicolumn{1}{|c|}{ Seyahat Türü } & Sayı & $\%$ \\
\hline İş & 164 & 31,54 \\
\hline Yalnız & 15 & 2,89 \\
\hline Çift & 71 & 13,65 \\
\hline Aile & 139 & 26,73 \\
\hline Arkadaş & 56 & 10,77 \\
\hline Belirtilmemiş & 75 & 14,42 \\
\hline Toplam & 520 & 100 \\
\hline
\end{tabular}

Tablo 3'te şikâyette bulunan kişilerin seyahat türleri yer almaktadır. Seyahat türlerine göre şikâyette bulunan kişilerin \%31,54 ile en çok iş için seyahat edenler oluşturmaktadır. Ailesiyle 
seyahat edenlerin oranı \%26,73 ile ikinci sırada yer alırken, sırasıyla çift olarak seyahat edenler $\% 13,65$ ile üçüncü ve arkadaşlarıyla seyahat edenler \%10,77 ile dördüncü sırada yer almaktadır. Yalnız seyahat edenlerin oranı ise \%2,89 ile en son sırada yer alırken şikâyette bulunan kişilerin $\% 14,42$ 'si seyahat türünü belirtmemiştir.

Tablo 4. Otel İşletmelerine Yönelik e-Şikâyet Kategorileri

\begin{tabular}{|l|c|c|}
\hline \multicolumn{1}{|c|}{ Kategori } & Sayı & $\%$ \\
\hline Otel Tesis İmkânları ve Özellikleri ile İlgili Şikâyetler & 266 & 20,28 \\
\hline Odalar ile İlgili Şikâyetler & 415 & 31,63 \\
\hline Yiyecek - İçecek ve Restoran ile İlgili Şikâyetler & 261 & 19,89 \\
\hline Yönetim ile İlgili Şikâyetler & 208 & 15,85 \\
\hline Personel ile İlgili Şikâyetler & 162 & 12,35 \\
\hline Toplam Şikâyet & 1312 & 100 \\
\hline
\end{tabular}

Çalışma kapsamında incelenen şikâyetler 5 ana kategori altında toplanmıştır. Tablo 4'e bakıldığında en fazla şikâyet bildirilen kategorinin 415 adet ve \%31,63 oran ile odalar ile ilgili şikâyetler olduğu daha sonra $266(\% 20,28)$ adet şikâyetle otel tesis imkânları ve özellikleri ile şikâyetlerin yer aldığı görülmektedir. Bu şikâyet kategorilerini sırasıyla $261(\% 19,89)$ adet şikâyet ile yiyecek-içecek ve restoran ile ilgili şikâyetler, $208(15,85)$ adet şikâyet ile otel yönetimine yönelik şikâyetler takip etmektedir. En az şikâyet bildirilen kategorinin 162 adet $(\% 12,35)$ ile personel ile ilgili şikâyetler olduğu tespit edilmiştir.

Tablo 5. Otel Tesis İmkân ve Özellikleri ile İlgili e-Şikâyet Alt Kategorileri

\begin{tabular}{|l|c|c|}
\hline \multicolumn{1}{|c|}{ Otel Tesis İmkânları ve Özellikleri ile İlgili Şikâyetler } & Sayı & $\%$ \\
\hline Otel Mimarisi ve Görünümü & 53 & 19,92 \\
\hline $\begin{array}{l}\text { Otel Ortak Kullanım Alanları (Lobi, Wc, Spor Salonu, Çocuk Oyun } \\
\text { alanları vb.) }\end{array}$ & 34 & 12,78 \\
\hline Otopark Kapasitesi ve Hizmeti & 10 & 3,76 \\
\hline Otel Konumu, Erişilebilirliği & 53 & 19,92 \\
\hline Gürültü & 37 & 13,92 \\
\hline Havuz, SPA ve Hamam (Temizliği, Bakımı, Yeterliliği) & 61 & 22,93 \\
\hline İnternet & 24 & 5,78 \\
\hline Eğlence & 18 & 6,77 \\
\hline
\end{tabular}

Tablo 5'te Otel tesis imkân ve özellikleri ana kategorisinin altında havuz, SPA ve hamam ile ilgili şikâyetlerin \%22,93 oran ile ilk sırada yer aldığı görülmektedir. Bu kategoride yer alan 
şikâyetlerin içeriğine bakıldığında hamam ve SPA'ların temizliğinin yetersiz olduğu, havuzların boyutlarının küçük olduğu, soyunma alanlarının ve ekipmanların eski olduğu şeklindeki şikâyetlerin oranlarının yüksek olduğu tespit edilmiştir. İkinci sırada otel mimarisi ve görünümü $(\% 19,92)$ ve otel konumu, erişilebilirliği $(\% 19,92)$ ile ilgili şikâyetler yer almaktadır. Bu alt kategori kapsamında şikâyette bulunan kişiler genel olarak çalışmada incelenen otelleri görünüm ve mimari açısından alışık oldukları 5 yıldızlı otellerden farklı ve yetersiz bulduklarını belirtmişlerdir. Lobi, giriş, tuvalet, spor salonları, çocuk oyun alanları ve asansörler gibi otel ortak kullanım alanları hakkında şikâyet bildirenlerin oranı \%12,78 ile beşinci sırada yer almaktadır. Ayrıca şikâyetlerin \%13,92'sinin gürültüyle ilgili olduğu görülmektedir. Şikâyette bulunan kişiler buna sebep olarak otellerin birçoğunun şehir merkezlerinde yer alması, oda ses yalıtımlarının zayıf olması ve özellikle Körfez ülkelerinden gelen misafirlerin çok gürültü yapmalarını göstermişlerdir. Buna ek olarak Doğu Karadeniz'de yer alan otellerin bir kısmı Karadeniz Sahil Yolu kenarında bulunmakta ve dolayısıyla yüksek miktarda trafik gürültüsüne maruz kalmaktadır. Otellerle ilgili şikâyet bildirilen diğer bir konunun da \%5,78 ile internet erişimi ile ilgili olduğu görülmektedir. Misafirlerin daha çok kablosuz internet kapsam alanının yetersiz olmasından ve internet hızının yavaş olmasından şikâyetçi oldukları tespit edilmiştir. Otel misafirlerinin otellerde yeterli derecede eğlence ve aktivite çeşitliliği olmaması $(\% 6,77)$ konusunda da şikâyette bulundukları belirlenmiştir. Bu ana kategori altında en az şikâyet alan konu ise otopark kapasitesi ve hizmetidir. Otopark konusunda yapılan şikâyetlerin genellikle bazı otellerin tam hazır olmadan açıldıkları dönemlerde yapıldığı tespit edilmiştir.

Tablo 6. Odalar ile İlgili e-Şikâyet Alt Kategorileri

\begin{tabular}{|l|c|c|}
\hline \multicolumn{1}{|c|}{ Odalar ile İlgili Şikâyetler } & Sayı & $\%$ \\
\hline Oda Konumu ve Mimarisi & 66 & 15,9 \\
\hline Tuvalet, Banyo Durumu (Temizlik, Sıcak Su, Bakımsızlık) & 66 & 15,9 \\
\hline Ekipman ve Malzeme Yetersizliği & 95 & 22,9 \\
\hline Oda Temizliği & 56 & 13,5 \\
\hline Mobilya & 41 & 9,88 \\
\hline Oda Servisi & 24 & 5,78 \\
\hline Havasız/Boğucu/Karanlık Oda & 25 & 6,02 \\
\hline Mini Bar & 18 & 4,34 \\
\hline
\end{tabular}

Tablo 6' da odalar ilgili şikâyet ana kategorisi altında en fazla şikâyet alan kategorinin ekipman ve malzeme yetersizliği $(\% 22,9)$ olduğu görülmektedir. Bu kategoriyi oda konumu ve mimarisi ile tuvalet-banyo durumu $(\% 15,9)$ aynı oranlarla takip etmektedir. Tuvalet banyo durumu alt kategorisinde şikâyette bulunan misafirlerin genel olarak tuvalet ve banyoların temiz olmaması, su basıncının yeterli olmaması ve tuvalet banyoların bakımsız ve eski olmasından şikâyetçi oldukları tespit edilmiştir. Oda konum ve mimarisi alt kategorisinde şikâyette bulunanlar ise genellikle odaların otel iç mekânına, oto parka veya görüntü olarak rahatsız edici yerlere bakmasından şikâyette bulunmuşlardır. Misafirlerin diğer şikâyette bulundukları kategoriler sırasıyla oda temizliği $(\% 13,5)$, mobilya $(\% 9,88)$ ve havasız/boğucu/karanlık oda $(\% 6,02)$ olarak 
devam etmektedir. Odalar ile ilgili şikâyetler içerisinde en az şikâyet alan kategoriler oda servisi $(\% 5,78)$ ile mini bar $(\% 4,34)$ olmuştur.

Tablo 7. Yiyecek - İçecek ve Restoran ile İlgili e-Şikâyet Alt Kategorileri

\begin{tabular}{|l|c|c|}
\hline \multicolumn{1}{|c|}{ Yiyecek- İçecek ve Restoran ile İlgili Şikâyetler } & Sayı & $\%$ \\
\hline Restoran Konumu - Özellikleri (Büyüklük, Yoğunluk, Temizlik vb.) & 37 & 14,18 \\
\hline Yiyecek ve İçecek Çeşitliliği & 102 & 39,08 \\
\hline Yiyecek Lezzet ve Kalitesi & 76 & 29,12 \\
\hline Sunum/Servis & 46 & 17,62 \\
\hline
\end{tabular}

Tablo 7'de yiyecek-içecek ve restoran ile ilgili şikâyetlerin alt kategori sayıları ve oranları yer almaktadır. Yiyecek-içecek ve restoran ile ilgili şikâyetlerin oranlarına bakıldığında otel misafirlerinin en çok yiyecek/içecek çeşitliliği $(\% 39,08)$ konusunda şikâyette bulundukları görülmektedir. Özellikle bazı otellerde içecek çeşitliliği ile ilgili çok sayıda şikâyet olduğu tespit edilmiştir. Bu otellerin genellikle alkollü içecek servisi yapmadıkları veya içecek seçeneklerinin çok kısıtlı olduğu şikâyet konusu edilmektedir. Misafirlerin ayrıca yiyecek lezzet ve kalitesinden de önemli ölçüde $(\% 29,12)$ şikâyette bulundukları görülmektedir. Yiyecek-içecek ve restoran ile ilgi şikâyetler kategorisinde bu şikâyetleri sırasıyla sunum/servis $(\% 17,62)$, restoran konumu ve özellikleri $(\% 14,18)$ takip etmektedir.

Tablo 8. Yönetim ile İlgili e-Şikâyet Alt Kategorileri

\begin{tabular}{|l|c|c|}
\hline Yönetim ile İlgili Şikâyetler & Sayı & $\%$ \\
\hline Fiyatlar ve Ücretlendirme & 73 & 35,1 \\
\hline Yabancı Müşterilere Farklı Hizmet Verilmesi / Ayrımcılık Yapılması & 48 & 23,08 \\
\hline Yönetim Yetersizliği - İlgisizliği & 56 & 26,92 \\
\hline Yanıltıı Bilgilendirme & 31 & 14,9 \\
\hline
\end{tabular}

Tablo 8'e bakıldığında yönetim ile ilgili şikâyetler kategorisinde en fazla şikâyette bulunulan alt kategorinin \%35,1 ile fiyatlar ve ücretlendirme olduğu görülmektedir. Otel misafirlerinin $\% 26,92$ 'si otel yönetimlerinin yetersiz ve ilgisiz olmasıyla ilgili şikâyette bulunmuşlardır. Ayrıca otellerin yabancı otel misafirlerine farklı hizmet verdikleri ve otel misafirleri arasında ayrımcllık yaptıklarını belirtenlerin oranı da \%23,08 olarak tespit edilmiştir. Bu kategoride şikâyette bulunan misafirlerin çoğu körfez ülkelerden gelen misafirlere pozitif ayrımcılık yapıldığından ve kendileri ile ilgilenilmediğinden şikâyetçi olmuşlardır. Yönetim ile ilgili şikâyetler kategorisinde yer alan bir diğer alt kategorinin ise \%14,9 oran ile otel işletmelerinin yanıltıcı bilgilendirme yapmaları olduğu görülmektedir. Bu alt kategoride şikâyet bildirenlerin birçoğunun rezervasyon yaptıkları odayla kaldıkları odanın farklı olması veya otel yönetimlerinin rezervasyon sürecinde verdikleri sözlerin otele geldiklerinde yerine getirilmemesinden şikâyetçi oldukları tespit edilmiştir. 
Tablo 9. Personel ile İlgili e-Şikâyet Alt Kategorileri

\begin{tabular}{|l|c|c|}
\hline Personel ile İlgili Şikâyetler & Sayı & $\%$ \\
\hline Personel Eksikliği & 25 & 15,43 \\
\hline Personel Tutum - Davranışı & 85 & 52,47 \\
\hline Mesleki Bilgi Becerisi Eksikliği & 52 & 32,1 \\
\hline
\end{tabular}

Tablo 9'da personel ile ilgili yapılan e-şikâyetlerin alt kategorileri yer almaktadır. Bu bölümde şikâyetler üç ana kategoride toplanmış ve şikâyette bulunan otel misafirlerinin genel olarak benzer şikâyetlerde bulundukları tespit edilmiştir. Personel ile ilgili yapılan e-şikâyetlerin oranlarına bakıldığında otel misafirlerinin en fazla şikâyette bulundukları kategorinin personel tutum ve davranışı $(\% 52,47)$ olduğu görülmektedir. Bu alt kategoriyi sırasıyla personel mesleki bilgi ve beceri eksikliği $(32,1)$ ve personel eksikliği $(\% 15,43)$ alt kategorileri takip etmektedir.

\section{TARTIŞMA, SONUÇ ve ÖNERILER}

Bu çalışmada Doğu Karadeniz'de faaliyet gösteren 5 yıldızlı konaklama işletmelerine yönelik yapılan çevrimiçi olumsuz yorum ve şikâyetler incelenmiştir. Tripadvisor.com ve sikayetvar.com web sayfalarında yer alan toplam 520 şikâyet incelenirken kullanıcıların genelde birden fazla konuda şikâyette bulunması sebebiyle 1312 adet şikâyet kategorilere ayrılmıştır.

Şikâyette bulunanların demografik bilgilerine bakıldığında şikâyet bildiren kişilerin yarısından fazlasının erkek olduğu ve iş için seyahat edenler ile ailesiyle seyahat edenlerin oranlarının yüksek olduğu, yalnız seyahat edenlerin oranlarının ise en düşük olduğu tespit edilmiştir. Yapılan şikâyetlere cevap verilme oranının illere göre farklılık gösterdiği ve toplamda $\% 57,31$ oranında kaldığı tespit edilmiştir. Bu dönüşlerin bir kısmının şikâyetin içeriğiyle ilgili olmayıp birçok şikâyete aynı cevabın verildiği görülmüştür.

Çalışma kapsamında yapılan içerik analizine göre şikâyetlerin; otel tesis imkânları ve özellikleri ile ilgili şikâyetler, odalar ile ilgili şikâyetler, yiyecek-içecek ve restoran ile ilgili şikâyetler, yönetim ile ilgili şikâyetler ve personel ile ilgili şikâyetler olmak üzere 5 ana kategori altında toplandığı belirlenmiştir. Bu kategorilere bakıldığında odalar ile ilgili şikâyetlerin en fazla şikâyet alan kategori olduğu tespit edilmiştir. Bu açıdan araştırma Sparks ve Browning (2010)'in araştırmasıyla benzerlik gösterirken literatürde yer alan diğer birçok çalışmadan farklılık göstermektedir. Gürkan ve Polat'ın (2014) Ege ve Akdeniz Bölgelerinde yaptıkları araştırmada yiyecek-içecek ile ilgili şikâyetler birinci sırada yer alırken Zengin ve Haliloğlu'nun (2020) Sakarya'da yaptıkları araştırmada otelin özellikleri ve imkânları, Ayyıldız ve Baykal'ın (2020) Kuşadası'nda yaptıkları çalışmada genel, Alrawadieh ve Demirkol'un (2015) İstanbul'da yaptıkları çalışmalarında ise hizmet kalitesinin düşük olması kategorileri en yüksek şikâyet alan konular olmuştur.

Odalarla ilgili şikâyetlerin alt kategorilerine bakıldığında ise odalarda ki ekipmanların yetersiz olması, tuvalet ve banyoların kirli ve bakımsız olması ve oda konum ve mimarisi en yüksek oranda şikâyet alan alt kategoriler olmuştur. Müşterilerin genel olarak klima ve isıtma sitemlerinin çalışmaması veya yetersiz olmasından ve cam ve balkon kapılarının bozuk olmasından şikâyetçi oldukları tespit edilmiştir. Bu durum bölgede yer alan 5 yıldızlı otel 
odalarının müşterilerin beklentilerini karşılayamadıklarını göstermektedir. Çalışma ekipman ve malzeme yetersizliği kategorisinde fazla şikâyet olması açısından Çulha vd., (2009), Zengin ve Haliloğlu (2020), Ayyıldız ve Baykal'ın (2020) çalışmalarıyla benzerlik göstermektedir. Ana kategoriler içerisinde personel ile ilgili şikâyetlerin oranının en düşük olduğu tespit edilmiştir. Personel ile ilgili şikâyetlerin alt şikâyet kategorilerine bakıldığında personel tutum ve davranışı ile ilgili şikâyetlerin çok olması dikkat çekmektedir. Literatürde yer alan Çulha vd., (2009), Barreda ve Bilgihan (2013), Zengin ve Haliloğlu (2020), Ayyıldız ve Baykal (2020) ve Alrawadieh ve Demirkol (2015) gibi birçok çalışmada da personel tutum ve davranışı ile ilgili şikâyetlerin çok olduğu dikkat çekmektedir. Bu yapılan çalışmaların genellikle turizm bölgelerinde yer alan konaklama işletmelerini ele alması ve Doğu Karadeniz'de yer alan otellerin çoğunun şehir oteli statüsünde kabul edilebilecek oteller olmasının araştırma sonuçlarının farklılık gösterme sebeplerinden bir tanesi olabileceği değerlendirilmektedir.

Dikkat çeken bir diğer şikâyet alt kategori ise yabancı müşteriler lehine ayrımcılık yapılmasıdır. Çalışma literatürde yer alan çalışmalardan bu kategori açısından farklılık göstermektedir. Doğu Karadeniz son yıllarda Orta Doğu ve Körfez ülkelerinden gelen turistler için önemli bir destinasyon olarak dikkat çekmektedir. Şikâyette bulunan kişilerin özellikle Orta Doğu ve Körfez ülkelerinden gelen misafirlere yönelik pozitif ayrımcılık yapılmasından, yerli misafirlere değer verilmemesinden şikâyetçi oldukları tespit edilmiştir. Şikâyette bulunan misafirlerin, yabancı misafirlerin aşırı gürültü yapmaları ve saygısız davranışlarda bulunmalarına rağmen otel yönetimleri tarafından hoş görülmelerinden ve rahatsızlıklarını bildirdikleri halde herhangi bir uyarı yapılmadığından şikâyetçi oldukları görülmektedir. Ayrıca şikâyette bulunan misafirlerin yorumlarına bakıldığında yabancı misafirlerin döviz bırakmalarını ve konaklama işletmelerinin tamamen para odaklı davranmaların bu pozitif ayrımcllı̆ga sebep olarak gördükleri tespit edilmiştir.

Otel tesis imkân ve özellikleri ile ilgili şikâyetler ana kategorisi altında ise en çok şikâyet alan alt kategorinin havuz, SPA ve hamam ile ilgili şikâyetlerin olduğu tespit edilmiştir. Çalışma bu açıdan Alrawadieh ve Demirkol'un (2015) çalışmasıyla benzerlik göstermektedir. Otel, konumu ve erişilebilirliği ile otelin mimarisi ve görünümü diğer şikâyet alan konular olarak dikkat çekmektedir. En az şikâyet alan kategoriler ise otopark ve internet alt kategorileri olarak belirlenmiştir. Diğer şikâyette bulunulan kategorilere bakıldığında müşterilerin aldıkları hizmete göre ödedikleri ücretin yüksek olmasından, yiyecek ve içecek çeşitliliğinin ve kalitesinin düşük olmasından, otellerin gürültülü olmasından ve personelin mesleki bilgi becerilerinin düşük olmasından şikâyetçi oldukları tespit edilmiştir.

Çalışmanın sınırlılıkları ile ilgili olarak, bu çalışmanın yalnızca iki web sitesinde (TripAdvisor ve Sikayetvar) yer alan sınırlı bir şikâyet topluluğunu incelediğini belirtmek önemlidir. Ayrıca, bu çalışma çevrimiçi verilerle çalışmanın bir başka sınırlılığını daha ortaya koymaktadır ki bu, çevrimiçi şikâyetlerin ne amaçla yapıldığı ve ne kadar güvenilir olduğunun tespit edilmesinin zor olmasıdır (Vasquez, 2011: 1714). Öz-bildirim ile ilgili geleneksel olarak var olan güvenirlik eksikliğinin; kimlik, özgünlük ve amaç tespitinin zor olduğu çevrimiçi ortamlarda daha da zor olduğu göz ardı edilmemelidir (Li vd., 2020: 225-239).

Çalışma sonucunda ortaya çıkan şikâyet kategorileri ışığında otellerin odalarında bulunan ekipman ve malzemeleri yenilemelerinin ve oda temizliğine daha fazla önem göstermelerinin önemli olduğu görülmektedir. Ayrıca yiyecek ve içecek çeşitliliğinin müşteri beklentilerine göre tekrar gözden geçirilmesi gerekmektedir. Otel yönetimleri rezervasyon yapan müşterilere verdikleri sözün arkasında durmalı ve müşterilere yanıltıcı bilgi vermekten kaçınmalıdırlar. Otellerde özellikle yabancı dil bilen turizm alanında eğitim almış personeller istihdam edilmelidir. Buna ek olarak otel yönetimlerinin mevcut personellerine mesleki bilgi, davranış ve iletişim becerilerini arttırmaya yönelik hizmet içi eğitim programları düzenlemelerinin müşteri 
memnuniyetinin sağlanabilmesi için olumlu etki yaratacağı düşünülmektedir. Otellerde yer alan müşteri ilişkileri yönetiminin çevrimiçi müşteri şikâyetlerine daha fazla odaklanması ve müşterilerin şikâyetçi oldukları sorunları gidermeye yönelik cevaplar vermesi otel imajına olumlu katkı sağlayabilir. Bu şikâyetleri okuyan tüketicilerin aynı zamanda otellerin şikâyetleri çözüp çözmediğini de görebildiklerinin göz ardı edilmemesi oteller açısından önem arz etmektedir.

Otellerde yer alan müşteri ilişkileri yönetimi çevrimiçi müşteri şikâyetlerine daha fazla odaklanması ve müşterilerin şikâyetçi oldukları sorunları gidermeye yönelik cevaplar vermesinin otel imajına katkıda bulunacağı düşünülmektedir. Bu şikâyetleri okuyan tüketicilerin aynı zamanda otellerin şikâyetleri çözüp çözmediğini de görebildiklerinin göz ardı edilmemesi oteller açısından önem arz etmektedir.

Çalışma kapsamında Doğu Karadeniz'de yer alan 5 yıldızlı oteller incelenmiş olup daha sonra yapılacak çalışmalarda diğer konaklama işletmelerinin de araştırmaya dâhil edilmesi ve çalışma kapsamının genişletilmesinin daha kapsamlı bir sonuca ulaşılmasına yardımcı olacağı düşünülmektedir. Araştırma kapsamında tespit edilen Körfez ülkeleri ve Orta Doğu'dan gelen misafirlere yönelik pozitif ayrımcılık yapıldığ görüşmeler yapılarak şikâyet sebepleri incelenebilir. Ayrıca çalışmada verilerin alındığı iki şikâyet platformu haricinde konaklama işletmelerinin sosyal medya hesapları veya diğer yorum web sayfaları çalışmalara dâhil edilerek daha fazla müşteri şikâyetine ulaşılabilir. Bunlara ek olarak daha sonra yapılacak çalışmalarda otellerin şikâyetlere verdiği cevapların da incelenmesi önerilebilir.

\section{KAYNAKÇA}

Aktan, E. ve Koçyiğit, M. (2016). Sosyal Medya'nın Turizm Faaliyetlerindeki Rolü Üzerine Teorik Bir İnceleme, Dumlupinar Üniversitesi Sosyal Bilimler Dergisi, ICEBSS Special Issue: 62-73.

Alrawadieh, Z. ve Demirkol, Ş. (2015). Konaklama İşletmelerinde E-Şikâyet Yönetimi: İstanbul'daki Beş Yıldızlı Oteller Üzerinde Bir Çalışma, Nişantaşı Üniversitesi Sosyal Bilimler Dergisi, 3(1): 130-148.

$\mathrm{Au}$, N., Buhalis, D. and Law, R. (2009). Complaints on The Online Environment-The Case of Hong Kong Hotels, Information and Communication Technologies in Tourism, 1, 73-85.

Aymankuy, Ş. Y. (2011). Yerli Turistlerin İnternet Ortamındaki Şikâyetlerinin Satın alma Kararlarına Etkileri, Balıkesir Üniversitesi Sosyal Bilimler Enstitüsü Dergisi, 14(25), 218-238.

Ayyıldız, A. Y. ve Baykal, M. (2020). Otel İşletmelerine Yönelik E-Şikâyetlerin İçerik Analizi ile İncelenmesi: Kuşadası 5 Yıldızlı Otel İşletmeleri Örneği, OPUS Uluslararası Toplum Araştırmaları Dergisi, 16(30), 2659-2683.

Barreda, A. and Bilgihan, A. (2013). An Analysis of User-Generated Content for Hotel Experiences, Journal of Hospitality and Tourism Technology, 4(3), 263-280.

Bell, S. J., Mengüç, B. and Stefani, S. L. (2004). When Customers Disappoint: A Model of Relational Internal Marketing and Customer Complaints, Journal of the Academy of Marketing Science, 32(2), $112-126$. 
Berry, R., Tanford, S., Montgomery, R. and Green, A. (2018). How We Complain the Effect of Personality on Consumer Complaint Channels, Journal of Hospitality \& Tourism Research, 42(1), 74101

Burucuoğlu, M. (2011). Müşteri Memnuniyeti ve Sadakatini Arttırmada Müşteri Şikâyetleri Yönetiminin Etkinliği: Bir Örnek Olay İncelemesi. Karamanoğlu Mehmetbey Üniversitesi, Sosyal Bilimler Enstitüsü İşletme Anabilim Dalı, Yüksek Lisans Tezi, Karaman

Çakar, K., Kalbaska, N., Inanir, A. and Sahin Oren, T. (2018). e-Visa's Impacts on Travel and Tourism: The Case of Turkey, Journal of Hospitality and Tourism Technology, 9(1), 13-31.

Çakar, K. and Aykol, Ş. (2019). Innovative Service Experiences of Travelers Visiting High-Tech Hotels: The Case of Eccleston Square Hotel, London, Turizam, 23(3), 120-132.

Çakar, K. and Uzut, I. (2020). Exploring the Stakeholder's Role in Sustainable Degrowth within the Context of Tourist Destination Governance: The Case of Istanbul, Turkey. Journal of Travel \& Tourism Marketing, 37(8-9), 917-932.

Çakıcı, C. ve Güler, O. (2015). Şikâyet Yönetimi. (Editör) Kılıç, B. ve Öter, Z.: Turizm Pazarlamasında Güncel Yaklaşımlar içinde (ss.217-257) İstanbul: Beta Yayıncllık.

Camprubí, R. and Coromina, L. (2016). Content Analysis in Tourism Research, Tourism Management Perspectives, 18,134-140.

Çulha, O., Hacıoğlu, G. ve Kurt, G. (2009). Otel Müşterilerinin e-Şikâyetlerine Yönelik Bir İçerik Çözümlemesi, Seyahat ve Otel İşletmeciliği Dergisi, 6(4), 42-49.

Day, R. L. and Landon, E. L. Jr (1977). Towards a Theory of Consumer Complaining Behavior. (Editor) Woodside, A.G. Sheth I.N. and Bennet P.D. Consumer and Industrial Buying Behaviour içinde (ss. 229-242) North-Holland, New York.

Erol, G. Örgün, E. ve Keskin, E. (2019). Sosyal Medyada Restoran İmajı: Kapadokya Örneği, Journal of Tourism and Gastronomy Studies, 7(4), 3290-3302.

Garay, L. (2019). Visitspain. Breaking Down Affective and Cognitive Attributes in The Social Media Construction of The Tourist Destination Image. Tourism Management Perspectives 32 (100560), 1-11.

Gürkan, G. Ç. ve Polat, D. D. (2014). Ege ve Akdeniz Bölgesi'nde Faaliyet Gösteren Resort Konaklama İşletmeleri Hakkında Yapılan Şikâyetler Üzerine Nitel Bir Araştırma, Seyahat ve Otel İşletmeciliği Dergisi, 11(2), 45-61.

Harrison-Walker, L.J. (2001). e-Complaining: A Content Analysis of an Internet Complaint Forum, Journal of Services Marketing, 15(5), 397-412.

Hirschman, A. O. (1970). Exit, Voice, and Loyalty: Responses to Decline in Firms, Organizations, and States, Harvard University Press: Cambridge.

Hsu, C. L. and Lin, J. C. C. (2008). Acceptance of Blog Usage: The Roles of Technology Acceptance, Social Influence and Knowledge Sharing Motivation, Information \& Management, 45(1), 65-74.

http://www.sikayetvar.com/> (Erişim Tarihi: 15.06.2021).

https://www.similarweb.com/top-websites/category/travel-and-tourism/travel-and-tourism/> (Erişim Tarihi: 06.06.2021).

https://tripadvisor.mediaroom.com/us-about-us > (Erişim Tarihi: 25.05.2021). 
Kemp, S. (2020). Digital 2020: Global Digital Overview. https://datareportalcom/reports/digital2020-global-digital-overview > (Erişim Tarihi: 18.05.2021).

İnanır, A. (2019). Turistik Destinasyon Yönetiminde Paydaşlar Arası İlişkiler: Göller Yöresi Örneği, Türk Turizm Araştırmaları Dergisi, 3(3), 517-541.

İnanır, A. ve Ongun, U. (2019). Yeşilova Salda'yı Ziyaret Eden Turistlerin Deneyimlerinin İncelenmesi, Türk Turizm Araştırmaları Dergisi, 3(4), 1028-1041.

İnanır, A., Uslu, A., ve Çaprak, D. (2019). Sakin Şehir ve Kırsal Turizm: Eğirdir İlçesi'nde Bir Araştırma, Cittaslow and Rural Studies, 7(3), 1711-1726.

Kavoura A. (2014). Social Media, Online Imagined Communities and Communication Research, Library Review, 63, 490-504.

Krippendorff, K. (2004). Content Analysis: An Introduction to its Methodology. Sage Publications: California.

Kowalski, R. M. (1996). Complaints and Complaining: Functions, Antecedents, and Consequences, Psychological Bulletin, 119, 179-196.

Landon Jr, E. L. (1980). The Direction of Consumer Complaint Research, Advances in Consumer Research, 7(1), 335-338

Lertputtarak, S. and Samokhin, D. (2017). Customer Complaints about Four Star Hotels in Pattaya, Thailand, e-Review of Tourism Research, 14(5/6), 214-240.

Li, M., Ma, Y. and Cao, P. (2020). Revealing Customer Satisfaction with Hotels Through MultiSite Online Reviews: A Method Based on the Evidence Theory, IEEE Access, 8, 225226-225239.

Lu, W. and Stepchenkova, S. (2015). User-Generated Content as a Research Mode in Tourism and Hospitality Applications: Topics, Methods, and Software, Journal of Hospitality Marketing $\mathcal{E}$ Management, 24(2), 119-154.

Ly, B. (2020). Effect of Social Media in Tourism (Case in Cambodia), Journal of Tourism Hospitality, 9(1), 1-9.

Namkung, Y., Jang, S. S. and Choi, S. K. (2011). Customer Complaints in Restaurants: Do They Differ by Service Stages and Loyalty Levels?, International Journal of Hospitality Management, 30(3), 495-502.

Ongun, U., İnanır, A., ve Kılınç, O. (2019). Ağlasun İlçesinin Gastronomi Turizmi Potansiyelinin Belirlenmesi, Kültür ve Kırsal Turizme Entegrasyonu, Gastroia: Journal of Gastronomy and Travel Research, 3(4), 805-822.

Riesenberger, C. A. and Sousa, S. D. (2010). The 8D Methodology: An Effective Way to Reduce Recurrence of Customer Complaints. Proceedings of the World Congress on Engineering. 30 June - 2 July, London, UK.

Rogers, Ross, and Williams (1992). Personal Values and Purchase Dissatisfaction Response, Journal of Consumer Satisfaction, Dissatisfaction and Complaining Behavior, 5, 81-92.

Singh, J. (1990). Identifying Consumer Dissatisfaction Response Styles: An Agenda for Future Research, European Journal of Marketing, 24(6), 55-72.

Sigala, M., Christou, E. and Gretzel, U. (2012). Social Media in Travel, Tourism and Hospitality: Theory, Practice and Cases. Ashgate Publishing Ltd: Farnham, UK. 
Sparks, B.A. and Browning, V. (2010). Complaining in Cyberspace: The Motives and Forms of Hotel Guests' Complaints Online, Journal of Hospitality Marketing \& Management, 19, 797-818.

Susskind, A. M. (2005). A Content Analysis of Consumer Complaints, Remedies, and Repatronage Intentions Regarding Dissatisfying Service Experiences, Journal of Hospitality $\mathcal{E}$ Tourism Research 29(2), 150-169.

Tiago, M. T. P. M. B. and Veríssimo, J. M. C. (2014). Digital Marketing and Social Media: Why Bother?, Business Horizons, 57(6): 703-708.

Tronvoll, B. (2007). Customer Complaint Behaviour from The Perspective of The ServiceDominant Logic of Marketing, Managing Service Quality. 17, 601-620.

Vásquez, C. (2011). Complaints online: The Case of TripAdvisor, Journal of Pragmatics, 43 (6), 17071717.

Vinerean, S., Cetina, I., Dumitrescu, L. and Tichindelean, M. (2013). The Effects of Social Media Marketing on Online Consumer Behavior, International Journal of Business and Management, 8(14), 66-79.

Yüksel, A., Kılınç, U. and Yüksel, F. (2006). Cross-national Analysis of Hotel Customers' Attitudes Toward Complaining and Their Complaining Behaviours, Tourism Management, 27(1), 11-24.

Zengin, B. ve Haliloğlu, S. (2020). Konaklama İşletmelerine Yönelik E- Şikâyetlerin İncelenmesi: Sakarya Örneği, Safran Kültür ve Turizm Araştırmaları Dergisi, 3(1), 68-84.

Zheng, T., Youn, H. and Kincaid, C. S. (2009). An Analysis of Customers' E-complaints for Luxury Resort Properties, Journal of Hospitality Marketing \& Management, 18(7), 718-729. 